Revista de Economia Política, vol. 32, no 3 (128), pp. 389-411, julho-setembro/2012

\title{
Quinze anos de rigidez monetária no Brasil pós-Plano Real: uma agenda de pesquisa
}

\author{
ANDRE DE MELO MODENESI \\ RUI LYRIO MODENESI*
}

Fifteen years of monetary rigidity in Brazil after the Real Plan: a research agenda.The paper makes a review of literature and a research agenda on the anomaly of Brazilian monetary policy. Following a retrospect of the first 15 years after the Real Plan, there is a review of studies aiming to explain the high real interest rate. None of the summarized theses can completely explain the phenomenon. The main research opportunities are: deepening of empirical evidence of monetary policy efficacy loss; improvement in mensuration of its inefficacy; and improvement of alternative instruments to control inflation. The field of political economy is also fertile. One should assess the relevance of oligopolies as an explaining factor of persistence of high inflation.

Keywords: inflation; monetary policy; Selic.

JEL Classification: E31.

\section{INTRODUÇÃO}

A política monetária (PM) brasileira constitui verdadeira anomalia. Apesar de inaugurada em 1995 uma fase de relativa estabilidade de preços com o Plano Real (PR), o Banco Central do Brasil (BCB) tem mantido a taxa básica de juros (Selic) em níveis excessivamente elevados: o país vem alcançando recordes mundiais em termos de juros reais. Após a implementação do PR e adotado o regime de metas de inflação (RMI), em 1999, a expectativa era de que, na medida em que se fosse consolidando a

\footnotetext{
* Respectivamente, Professor da UFRJ, pesquisador do CNPq e diretor da Associação Keynesiana Brasileira; e-mail: amodenesi@gmail.com; e Economista; e-mail: rlmodenesi@gmail.com. Os autores agradecem os comentários de Fabio S. Erber (in memoriam), Luiz F. de Paula, L. C. Bresser-Pereira, Jennifer Hermann e Norberto M. Martins, isentando-os de qualquer responsabilidade por eventuais erros e omissões. Submetido: 6/junho/2011; Aprovado 31/agosto/2011.
} 
estabilização dos preços, a Selic passasse a ser significativamente reduzida, convergindo para níveis prevalecentes nas economias com preços estáveis. Não foi o que aconteceu. Mesmo a despeito da inflexão da política fiscal, com a geração de superávits primários, a partir de 1999. Entre esse ano e o de 2010, a Selic real média foi superior a $9 \%$ a.a. Embora tenha sido reduzida a partir do ano 2000, a Selic ainda permanece demasiadamente alta. Não obstante a rigidez da PM, a inflação vem-se mantendo em patamares que podem ser considerados elevados, principalmente com relação à experiência internacional. No período de 1995 a 2010, o IPCA ficou abaixo de 5\% em apenas quatro anos, atingindo média próxima a $7 \%$. Em suma, apesar da longa manutenção da Selic em níveis inusitados, a inflação tem cedido pouco.

O objetivo deste trabalho é apresentar uma agenda de pesquisa focada na anomalia em que se transformou a PM. São três seções além desta introdução. A primeira contém breve retrospecto desta política após o PR. A segunda seção traz uma resenha das teses que buscam explicar por que a Selic vem sendo perpetuada em níveis tão elevados: reduzida eficácia da PM; convenção pró-conservadorismo na PM; equilíbrios múltiplos da taxa de juros; fiscalista; e incerteza jurisdicional. $\mathrm{Na}$ terceira, é formulada uma agenda de pesquisa centrada no problema da taxa de juros. Assim como nos anos 1980, a pesquisa macroeconômica centrou-se no enigma da inflação inercial, atualmente seu foco deve deslocar-se para esse novo problema. Consolidada a estabilidade, a grande incógnita é como compatibilizá-la com uma política monetária normal. Em conjunto, as cinco teses deixam claro que se trata de fenômeno em que se entrecruzam causas de distinta natureza - econômica, institucional e de economia política. A principal conclusão é que não se pode esperar explicação única e simples, dada a complexidade do problema. Sem embargo, surpreende a persistente coexistência de taxas reais de juros anomalamente altas com elevados níveis de inflação. A propósito, há um conjunto amplo de evidências de que há falhas na transmissão da PM. A inflação tem-se mostrado pouco sensível ao nível de atividade econômica: é preciso uma retração de grandes proporções para se obter uma queda relativamente pequena da inflação. Por isso, o BCB não tem sido capaz de trazer o IPCA para menos de 4-5\% a.a. Daí a importância atribuída a essa tese que, junto com as teses da convenção pró-conservadorismo e do equilíbrio múltiplo dos juros, contribui para melhor compreender o fenômeno e aponta para a necessidade de reformulação da estratégia de combate à inflação.

\section{POLÍTICA MONETÁRIA PÓS-PLANO REAL}

O PR tornou-se um marco ao encerrar o ciclo de quase uma década de tentativas fracassadas de combate à inflação: planos Cruzado, Bresser, Verão, Collor I e II e Marcílio. ${ }^{1}$ Foi uma estratégia de estabilização de preços implantada em três fases: ajuste fiscal; desindexação substancial, ainda que parcial; e âncora cambial.

\footnotetext{
${ }^{1}$ Segundo Bresser-Pereira (1992), foram implementados onze planos de estabilização entre 1979 e 1991.
} 
O real foi mantido artificialmente sobrevalorizado, subordinando-se a política monetária ao objetivo de controlar o volume das reservas internacionais. As elevadas necessidades de financiamento do balanço de pagamentos (BP), o temor da volta da inflação e a geração de déficits primários, no primeiro governo do Presidente Cardoso, eram apontadas como principais justificativas para a excessiva rigidez da PM. Assim, a Selic real aproximou-se de 30\% a.a. (1995 e 1998). No quadriênio de 1995 a 1998, sua média foi superior a $22 \%$ a.a. ${ }^{2}$ Apesar do sucesso inequívoco do PR no controle da inflação e da preservação da estabilidade de preços nos anos subsequentes, o BCB permanece até hoje mantendo a Selic em patamares muito altos. Com isso, a PM brasileira distingue-se dos padrões internacionais: o país tem praticado as maiores taxas de juros reais do mundo.

Em 1999, a economia brasileira sofreu um ataque especulativo que culminou na substituição da âncora cambial pelo RMI. Apesar do overshooting cambial não ocorreu a temida recidiva inflacionária. Consolidada a estabilidade de preços, esperava-se ver a Selic reduzida a níveis próprios das economias com preços estáveis. Isso não ocorreu — apesar da inflexão na política fiscal após 1999, com o cumprimento de metas de superávit primário de cerca de 4\% do PIB. ${ }^{3}$ Entre 1999 e 2010, a Selic real manteve-se acima de um dígito em cinco ocasiões (1999, 2000, 03, 05 e 06) e sua média superou $9 \%$ a.a. É verdade que a Selic real caiu de forma não desprezível, sobretudo a partir do ano 2000 — porém ainda mantém-se em patamar muito alto. A PM brasileira constitui uma anomalia no cenário mundial. Grosso modo, a taxa de juros real do país foi mais do que o dobro da média da América Latina (AL), entre 1995 e 2008. No período, a taxa de juros real no Brasil foi sistematicamente superior à média dos emergentes.

Entretanto, a inflação no Brasil tem permanecido elevada. Entre 1995 e 2010, o IPCA manteve-se abaixo de 5\% em apenas quatro ocasiões (1998, 2006, 07 e 09 ), e sua média beirou os $7 \%$. Neste sentido, pode-se afirmar que a PM tem sido pouco eficaz: apesar da longa persistência dos juros em níveis exorbitantes, a inflação tem cedido pouco. Vale notar que, entre 1980 e 2008, houve forte redução da taxa de inflação dos principais países da AL; em cerca da metade deles, a inflação foi menor que $5 \%$ a.a., depois de 2000 . Note-se, ademais, que a inflação brasileira foi superior à média mundial, entre 1995 e 2008 . Com relação às economias em desenvolvimento, a inflação também se mostra elevada, sobretudo entre 2000 e 2007: a média do grupo aproximou-se de 6\%. Chama atenção o fato de que, apesar de praticar sistematicamente as maiores taxas de juros do mundo, o BCB não tenha sido capaz de cumprir as metas de inflação por três anos seguidos (2001-03) — sinal de que ainda há problemas na transmissão da PM, anos após a redução do componente inercial da inflação, promovida pelo PR.

Quanto a suas consequências negativas, a rigidez monetária é uma das razões

\footnotetext{
${ }^{2}$ As fontes dos dados são BCB, IBGE e FMI.

${ }^{3}$ É verdade que o resultado primário é uma medida problemática da instância fiscal (Rodrigues e Bastos, 2010). O que importa salientar é que houve contração fiscal da ordem de $4 \%$ do PIB.
} 
para o fraco desempenho da economia brasileira, entre 1995 e 2010. O PIB real cresceu cerca de $3 \%$ na média do período, superando $5 \%$ apenas quatro vezes (2004, 07, 08 e 10). Tal resultado revela-se ainda pior quando comparado com o desempenho dos demais países emergentes que, de forma geral, têm crescido a taxas consideravelmente superiores e de forma sustentável. O câmbio também tende a se reduzir em resposta a um aumento na Selic. O alto diferencial entre os juros doméstico e externo contribui para o expressivo processo de valorização do real (a partir de 2003). O real é uma das moedas que mais se valorizaram recentemente: desde 2008, a taxa de câmbio média mantém-se próxima da observada em 1999. De fato, o câmbio tem sido um dos principais mecanismos de transmissão da PM, como mostrado por muitos autores. ${ }^{4}$ Essa valorização é temerária: desestimula exportação e estimula importação. Isso contribui para limitar o crescimento e torna o financiamento do BP dependente da entrada de voláteis capitais de curto prazo de caráter especulativo.

Finalmente, as contas públicas têm sido muito afetadas. A despeito de superávits primários robustos, da ordem de $4 \%$ do PIB, em média, registraram-se déficits nominais entre $1,5 \%$ e $5,8 \%$ do PIB, entre 1999 e 2008 . A despesa com o pagamento de juros da dívida pública foi consideravelmente superior aos superávits primários do setor público. Nesse sentido, tem ocorrido dominância monetária: a PM tem contaminado as contas públicas (Sayad, 2005). ${ }^{5}$ Isso é exacerbado por uma peculiaridade da dívida pública, a existência de títulos indexados à taxa básica de juros. As Letras Financeiras do Tesouro Nacional (LFT) são títulos pós-fixados que evoluem de acordo com a Selic. Como constituem parcela relevante do estoque da dívida, a manutenção da Selic em níveis muitos elevados resulta em um custo financeiro igualmente alto: o pagamento de juros da dívida foi, em média, superior a $7 \%$ do PIB, no período. ${ }^{6}$

Em síntese, o PR real foi bem-sucedido no combate à inflação. No entanto, a estabilidade vem-se apoiando em PM extremamente restritiva e, portanto, muito onerosa. É justamente em face dos custos associados à alta taxa de juros que o debate sobre a PM assume sua devida relevância. A estabilização monetária somente estará concluída com a reversão desse quadro. A primeira fase desse processo - a eliminação da alta inflação crônica — foi efetivada com sucesso há uma década e meia. Todavia, o alto custo que a sociedade brasileira vem pagando pela estabilidade de preços impede que tal conquista se torne perene ou politicamente sustentável (Fróes et al., 2005).

Falta, ainda, uma última etapa do processo de estabilização: uma flexibilização

\footnotetext{
${ }^{4}$ Por exemplo, Kregel (2004), Serrano (2006), Nogueira Jr. (2007), Arestis et al. (2009), Araújo e Modenesi (2010b) e Carvalho (2011).

${ }^{5}$ Bruno (2010) mostra evidência a favor de relação de causalidade (Granger) do fator acumulado da Selic real para a dívida pública.

${ }^{6}$ Uma alta da Selic determina, quase instantaneamente, um aumento da despesa com juros; diferentemente do que ocorre quando os juros são pré-fixados: o impacto é diferido no tempo.
} 
sustentável da PM. A redução dos juros para níveis próprios de economias estáveis - sem que isso implique a volta da inflação — é o grande desafio a ser cumprido pelo país. Já não é mais razoável controlar a inflação praticando as maiores taxas de juros do mundo. A estabilidade somente estará consolidada — tanto do ponto de vista econômico quanto político - quando o controle da inflação for associado a um mix de política econômica que viabilize o desenvolvimento econômico e, portanto, seja sustentável a longo prazo. Por isso, o problema da taxa de juros deve ocupar lugar destacado na agenda contemporânea.

\section{O DEBATE SOBRE O PROBLEMA DA TAXA DE JUROS}

É amplo o debate sobre as altas taxas reais de juros no Brasil. Para destacar a essência das análises que visam explicar o fenômeno, as classificamos em cinco teses: reduzida eficácia da PM; convenção a favor do conservadorismo na PM; equilíbrios múltiplos da taxa de juros; fiscalista; e incerteza jurisdicional. ${ }^{7}$

\section{1 - Reduzida Eficácia da Política Monetária}

O baixo grau de eficácia (e/ou a existência de problemas na transmissão) da PM tem sido indicado por muitos como causa da manutenção da Selic em níveis excessivamente elevados. ${ }^{8}$ Trata-se de tese com ampla aceitação, congregando autores de diversas orientações teóricas. A seguir, apresentam-se suas principais vertentes.

De acordo com Carvalho (2004, 2005), Kregel (2004) e Bacha e Oliveira Filho (2006), a inexistência de uma curva de rendimentos para prazos de maturação suficientemente longos seria o principal fator a reduzir a eficácia da PM. ${ }^{9}$ Como bem explica Carvalho (2005), isso implica que é na esfera de circulação financeira que se concentra a maior parcela da renda monetária:

[a] inexistência de uma curva de rendimentos com projeção temporal adequada e as elevadas taxas de juros de curto prazo deveriam contribuir para reduzir a eficácia da política monetária, já que, por um lado, a circulação financeira absorveria de modo permanente elevada proporção das variações das reservas criadas no processo de política monetária [...]. Além disso, os estímulos gerados pela política monetária não se transmi-

\footnotetext{
${ }^{7}$ O embrião dessa classificação encontra-se em Modenesi (2006b). Trata-se de esforço de tipificação das principais formulações, com inevitável simplificação. Apesar de serem apresentadas numa forma pura, as teses não são necessariamente mutuamente excludentes, podendo ser legitimamente combinadas.

${ }^{8}$ Sobretudo após a adoção do RMI, a PM praticamente reduziu-se ao uso da Selic.

${ }^{9}$ Ver Andina (2003), coordenado por F. J. C. Carvalho.
} 
tiriam aos segmentos mais longos, onde pudessem influenciar as escolhas de investimento real, pela inexistência daqueles segmentos (pp. 331-2).

O fato de o Tesouro Nacional (TN) ofertar um ativo singular, as LFT — título pós-fixado (i.e, sem risco de juros) e com alta liquidez e rentabilidade -, está na origem do problema. ${ }^{10}$ Cria-se anômala vinculação entre o mercado monetário e o de dívida pública via correção das LFT pela Selic — viabilizando a indexação de instrumentos financeiros ao Certificado de Depósito Interfinanceiro (CDI). Assim, o sistema bancário pode ofertar uma gama de instrumentos referenciados ao CDI e com alta liquidez. ${ }^{11}$ Enfim, a despeito de já consolidada a estabilidade de preços, ainda não se instaurou uma situação de "normalidade financeira" (Carvalho, 2005, p. 331).

Adicionalmente, o atrelamento entre os mercados monetário e de dívida implica que, além de ser um instrumento genuíno de PM, a Selic também baliza as ofertas de títulos do TN. Surge potencial descoordenação entre o BCB, que usa a Selic para controlar a inflação, e o TN que dela depende para se financiar. ${ }^{12}$ Como bem notado por Barbosa (2006), essa vinculação gera um efeito contágio entre a dívida pública e a PM. ${ }^{13}$ Assim, à taxa básica de juros deve ser acrescido um prêmio de risco: "Como subproduto da estreita inter-relação entre os títulos públicos e as reservas bancárias, a taxa básica de juros [Selic] incorpora um prêmio de risco” (p. 236; traduzido).

Com variado grau de abrangência e distintos enfoques, o problema das LFT também foi analisado por Bresser-Pereira e Nakano (2002), Nakano (2005, 2011), Franco (2005), Tenai (2006), Oreiro et al. (2007), Bresser-Pereira e Silva (2009), Paula (2009, 2011), Oreiro e Paula (2010), Delfim Netto (2011b), entre outros. ${ }^{14}$ Cabe destacar a importante contribuição de Barbosa (1991,1993, 2003, 2004, 2005) e o influente trabalho de Pastore (1996). O volume organizado por Bacha e Oliveira Filho (2006) contém uma parte dedicada ao tema. Note-se que o problema das LFT reúne autores ortodoxos e heterodoxos em torno da tese da baixa eficácia da PM.

A alta participação das LFT no estoque da dívida também pode originar um canal perverso de transmissão da PM ou um efeito renda financeira às avessas. Um aumento da taxa básica geraria um incremento de renda que — dependendo da

\footnotetext{
${ }^{10}$ A LFT foi criada como LBC (1986) para viabilizar o financiamento do TN, num quadro de ameaça de hiperinflação - evitando a prevista dolarização da economia. Estabilizados os preços, a LFT perde seu sentido original e deveria ter sido suprimida (Barbosa, 1982; Barbosa et al., 1995; Lopes, 1997).

${ }^{11}$ Os Fundos de Investimentos DI e os CDBs pós-fixados — referenciados ao CDI e com liquidez diária - são instrumentos singulares, que não existem em economias com preços estáveis. Constituem, assim, uma anormalidade da economia brasileira. Segundo a Anbid, em 2007 cerca de $25 \%$ dos ativos dos fundos mútuos brasileiros eram referenciados ao CDI, com maturidade de 1 dia; $40 \%$ eram alocados em fundos de renda fixa, com maturidade média de 1 ano; e somente $5 \%$ eram alocados em ações.

${ }^{12}$ Isso contribui para a multiplicidade de funções atribuídas à Selic por trás do equilíbrio instável do juro.

${ }^{13} \mathrm{O}$ efeito contágio é um dos elementos centrais da tese fiscalista.

${ }^{14}$ Esse problema se manifesta ainda nos altos spreads bancários (Paula e Pires, 2007; Silva et al., 2007).
} 
propensão marginal a poupar dos detentores de LFT — poderia ampliar a demanda agregada, aumentando os preços. A este respeito ver, por exemplo, Parreiras (2007, 2008), Pires (2008), Souza (2011) e Andrade e Pires (2009).

Segundo Nakano (2005), a eficácia da PM seria limitada, ainda, pela imperfeição do crédito como canal de transmissão. ${ }^{15}$ Sendo os bancos grandes detentores de LFT, também estariam suscetíveis ao efeito renda às avessas: seus ativos e receitas também cresceriam quando se eleva a Selic. Com mais recursos disponíveis, poderiam ampliar seus empréstimos. Mas só até certo valor crítico da taxa de juros - a partir do qual aumentaria o risco de inadimplência, em virtude do risco moral e da seleção adversa. Somente a partir desse limite, aumentos da Selic levariam os bancos a racionarem a oferta de crédito. Vale dizer, apenas para níveis de juros suficientemente elevados, o canal do crédito funcionaria no sentido esperado.

Como sintetiza Nakano (2011), o PR preservou, no setor financeiro, "o regime monetário do período de hiperinflação". Ele reafirma a necessidade de separar a taxa básica da taxa dos títulos do TN - a fim de que, extirpada essa anormalidade da economia brasileira, se recupere o potencial da PM:

[m]ais aloprado ainda é a taxa de juros das aplicações “overnight” pagar a mesma taxa Selic dos títulos de longo prazo do Tesouro Nacional: é lógico que o Banco Central aniquila a formação de um mercado de poupança aprisionando os poupadores no mercado de moeda, dando-lhes liquidez e remuneração correspondente à de títulos de longo prazo. Essa aberração tem que ser eliminada. Assim, desindexados os ativos financeiros, o novo instrumento de política monetária terá seu poder de ação multiplicado, tornando também desnecessária a manutenção dos juros num patamar tão elevado.

Carvalho (2005) bem ressalta que esse quadro institucional perverso se agrava pela importância de choques conjunturais de custo como fontes de pressão inflacionária - o que demandaria juros ainda mais elevados. ${ }^{16}$ Por sua vez, Marques e Fochezatto (2006) apresentam evidência empírica favorável à existência de um canal de custos na condução da PM brasileira. Admitindo-se que os preços são determinados por uma regra de mark up sobre os custos de produção, um aumento dos juros elevaria os custos que, por sua vez, poderiam ser repassados para os preços. Neste caso, o impacto inflacionário do aumento dos custos de produção pode anular efeito depressivo sobre os preços resultante de uma contração monetária.

\footnotetext{
${ }^{15}$ Ver Fonseca (2009).

${ }^{16}$ Os choques de custos, embora relevantes (Serrano, 2006; Vianna et al. 2010: cap. 4), não parecem suficientes para explicar a persistente resistência de a inflação ceder em resposta aos estímulos da PM - que também pode conter inflação com origem no lado da oferta: ao reduzir o nível de atividade coíbe o repasse dos custos para os preços (Davidson, 1978, 2003). Não se pretende, entretanto, minimizar a relevância das altas margens de lucro praticadas no país - que podem favorecer o repasse para os preços de elevação nos custos.
} 
Como proposto por muitos, outro fator a comprometer a eficácia da PM é a elevada participação dos preços administrados no IPCA (cerca de $30 \%) .{ }^{17}$ A quasi insensibilidade desses preços aos juros - aliada ao fato de que sua taxa de crescimento, muitas vezes, tem sido superior à inflação livre - requer que os preços livres sejam excessivamente represados, para compensar a forte pressão (direta e indireta) exercida pelos administrados sobre o IPCA, como ocorrido entre 1999 e 2006. Assim, a PM torna-se menos eficaz: a Selic deveria ser fixada em níveis elevados para manter a demanda agregada suficientemente reprimida de forma que seja possível o cumprimento da meta de inflação (Modenesi, 2003, 2005a). Ou seja, para uma dada meta, a existência de preços administrados implica que a Selic deve ser mantida em nível superior àquele que seria necessário, caso todos os preços fossem livres (Figueiredo e Ferreira, 2002).

Araújo e Modenesi (2010a) mostram que é baixa a sensibilidade da inflação à taxa de juros. Pela estimação de um modelo VAR, concluem que um aumento da Selic tem reduzido impacto deflacionário. Assim, o BCB precisaria mantê-la em níveis demasiadamente elevados para que as metas de inflação sejam minimamente cumpridas. Já o efeito de uma elevação da Selic sobre o nível de atividade é, claramente, negativo: a economia se desacelera. É aqui que os autores identificam problema no mecanismo de transmissão: um aumento dos juros contrai a demanda agregada; porém, o desaquecimento da economia não se transmite integralmente para os preços. Isto é, o arrefecimento da inflação é desproporcionalmente inferior à queda da atividade.

Favero e Giavazzi (2002) e Holland (2006), por exemplo, consideram que o fato de o BCB não possuir independência formal prejudicaria o funcionamento do canal das expectativas na transmissão da PM. Assim, PM a perderia credibilidade, comprometendo-se sua capacidade de coordenar as expectativas de inflação, o que tornaria necessária a fixação da Selic em níveis relativamente elevados. ${ }^{18}$

Finalmente, para Arida (2005), Franco (2005) e Giambiagi (2007), entre outros, os financiamentos do Banco Nacional de Desenvolvimento Econômico e Social (BNDES) e da Caixa Econômica Federal (CEF) — referenciados à Taxa de Juros de Longo Prazo (TJLP), sistematicamente fixada abaixo da Selic — reduziriam a eficácia da PM. Não dependendo da Selic, os investimentos financiados com esses recursos não seriam inibidos por PM restritiva. Destaque-se que o ex-Presidente do BCB foi reticente sobre a questão: "[u]ma maneira de dizer isso seria que diminui a eficiência da política monetária. Eu prefiro dizer que é possível, é plausível pensar, que possa demandar uma Selic um pouco maior" (Meirelles, 2010). Com efeito, dada a reduzida participação dessas operações no conjunto dos financiamentos concedidos pelo sistema financeiro, elas parecem ter limitado impacto sobre a eficácia da PM. ${ }^{19}$

\footnotetext{
${ }^{17}$ Bresser-Pereira e Nakano (2002) e Modenesi (2004, 2005b, 2006a), por exemplo.

${ }^{18}$ Sobre a coordenação de expectativas, ver Minella et al. (2003) e Bevilaqua et al. (2007).

${ }^{19}$ Os financiamentos do BNDES e da CEF referenciados à TJLP tiveram pequena participação no
} 
Ademais, suprindo a inexistência de um mercado de crédito de longo prazo, as eventuais externalidades negativas oriundas desses financiamentos - que comprometeriam a transmissão da PM — devem ser confrontadas com as externalidades positivas geradas pelos investimentos financiados. ${ }^{20}$ Além disso, em termos teóricos, a TJLP pode até potencializar a PM. Ao se praticar uma taxa de juros subsidiada para os investimentos, estimula-se, em detrimento do consumo, a FBCF - que no futuro se traduzirá em expansão do PIB potencial. Neste sentido, faz-se discriminação de preços a favor do investimento que, ao ampliar a oferta agregada futura, pode favorecer a estabilidade de preços, numa perspectiva dinâmica de longo prazo.

\section{2 - Equilíbrios Múltiplos da Taxa de Juros}

Bresser-Pereira e Nakano (2002) apontam a possibilidade de existência de equilíbrios múltiplos para a taxa de juros e invertem a relação de causalidade entre o risco-país e a taxa de juros: a partir de determinado patamar, a Selic se tornaria um fator determinante do risco de default, ao aumentar a despesa com juros da dívida pública. Neste caso, seria a taxa de juros doméstica que determinaria o risco-país, e não o oposto, como previsto pela teoria da paridade da taxa de juros. Essa inversão na causalidade entre a taxa de juros e o risco-país ficou conhecida como hipótese Bresser-Nakano. Ela desencadeou um importante debate, sendo inicialmente objeto de leitura ortodoxa por parte de Werlang (2002) que, por sua vez, provocou releitura heterodoxa de Câmara Neto e Vernengo (2002). Gomes e Holland (2003) apresentam evidência empírica favorável a esta hipótese.

Para Bresser-Pereira e Nakano (2002) o que, em termos gerais, explicaria os altos níveis de taxa de juros seria o fato de que as autoridades econômicas estariam atribuindo funções múltiplas à Selic: restringir a demanda agregada, para controlar a inflação; evitar a desvalorização cambial, a fim de conter inflação de custos; estimular a entrada de capitais, para equilibrar o BP; incentivar a compra de títulos, com vistas a financiar o déficit público; e diminuir o déficit comercial, via contenção da demanda. Dada essa multiplicidade de objetivos - alguns contraditórios entre si —, a elevação dos juros para realizar determinado objetivo tenderia a aprofundar desequilíbrios em termos de outros objetivos, requerendo recorrentes elevações da Selic.

Com base no modelo de Romer (2001), sugerem que, ao invés de se encontrar em um ponto de equilíbrio estável, a economia brasileira estaria em um equilíbrio instável - em que uma taxa de juros exageradamente elevada determinaria alta do risco de default. Nessas condições, o risco Brasil passaria a ser identificado com

total de crédito (1995-2010). Giambiagi (2007) estimou que, no caso do BNDES, o custo fiscal da diferença entre a Selic e a TJLP foi inferior a $0,5 \%$ do PIB (de 2000 a 2006) - relativizando o efeito negativo para a transmissão da PM: “a ênfase no tema [...] deve ser atribuída a um recurso de estilo literário" (p. 153).

${ }^{20}$ Paula (2012) ressalta "possíveis externalidades” decorrentes do crédito direcionado de longo prazo. 
o diferencial entre a taxa externa e a taxa doméstica de juros, deixando de traduzir o risco efetivo país. Independentemente da razão que os justificassem, aumentos na Selic seriam percebidos como elevação do risco-país, numa causação inversa à proposta pela teoria da paridade da taxa de juros. Oreiro (2002), Arida (2003a) e Blanchard (2004) também analisaram a possibilidade de múltiplas trajetórias temporais para os juros e o câmbio.

Em tom certamente irônico, concluem Bresser-Pereira e Nakano (2002) que “(s)e o governo brasileiro estabelece uma taxa de juros tão alta, deve ser mesmo um país arriscado" (p. 170). As altas taxas de juros constituiriam armadilha decorrente da atribuição de múltiplas funções à Selic:

[é] evidente que um único instrumento não pode alcançar simultaneamente todos esses objetivos. Além do mais, esses objetivos são contraditórios. A elevação da taxa de juros pode permitir o alcance de um objetivo, mas caminhará na direção oposta aos outros, aprofundando os desequilíbrios macroeconômicos. [...]. Dada a multiplicidade de objetivos, a taxa real de juros ao longo dos últimos anos tem sido a mais alta do mundo. (Bresser-Pereira e Nakano, 2002, p. 163)

Em suma, sendo a Selic usada para atingir objetivos incompatíveis, o resultado final seria uma taxa de juros excessivamente elevada. Acima de certo patamar, a Selic não mais atingiria um equilíbrio estável, conformando-se, ao invés, equilíbrio instável - invertendo-se a causalidade entre o risco-país e a taxa de juros.

\section{3 - Convenção Pró-Conservadorismo na Política Monetária}

Bresser-Pereira e Nakano (2002), Nakano (2006) e Erber (2008a, 2008b, $2011)$ inspiram-se no conceito de convenção desenvolvido por Keynes $(1936,1937)$ para dar mais uma explicação para o problema da taxa de juros.

Bresser-Pereira e Nakano (2002) originalmente propuseram que a autoridade monetária incorporara a convenção de que há um piso consideravelmente elevado para a Selic: "[d]epois da persistente manutenção da taxa de juros em nível muito elevado é natural que surja o medo de redução, e que esse nível se torne uma convenção" (p. 169).

Nakano (2006) critica a lentidão do ciclo de redução da Selic iniciado em 2005. A inflação estaria controlada e não haveria pressão de demanda — o desemprego era alto; a produção industrial apresentou queda; e o superávit primário foi da ordem de $5 \%$-, o que não justificaria a parcimônia do Copom em reduzir a Selic. A conjuntura internacional também seria propícia - o país tinha alto saldo em conta-corrente; o risco Brasil estava no nível mais baixo da série histórica; a economia internacional estava em expansão; e as condições internacionais de liquidez eram favoráveis -, o que possibilitaria uma queda mais acentuada dos juros. Assim, a morosidade no processo de diminuição da Selic somente se explicaria em função da aceitação por parte do BCB de uma convenção de que: o juro de equilíbrio seria 
de cerca de $14 \%$ a.a.; e o Copom deveria basear-se em uma regra de Taylor que suavizasse as variações da Selic.

Erber $(2008 \mathrm{a}, 2011)$ contribui para o aprofundamento dessa tese, sugerindo que a excessiva rigidez monetária somente poderia ser explicada pelo viés ${ }^{21}$ da economia política. ${ }^{22}$ As altas taxas de juros não configurariam problema de natureza exclusivamente macroeconômica. Seriam o resultado de uma influente coalizão de interesses formada em torno da manutenção dos juros em níveis elevados. ${ }^{23}$ Como o autor bem ressalta, há uma coalizão de interesses enraizada em torno do binômio juros altos-valorização cambial. Mas não se trata de uma típica situação em que o agente (BCB) é capturado pelo principal (rentistas). A coalizão é benéfica não só para os rentistas ${ }^{24}$ - que lucram com aplicações financeiras -, como também para o próprio $\mathrm{BCB}$, que se beneficia da reputação de ser um banco central conservador. Em suas palavras:

[e]xiste, pois, uma ampla e poderosa constelação de interesses, estruturada ao longo do tempo em torno à combinatória altos juros-câmbio valorizado, que estabeleceu uma convenção que estes elementos são essenciais para o desenvolvimento do país. [...]. Esta coalizão de interesses tem poderosos instrumentos para consolidar e difundir sua convenção de desenvolvimento. O mais explícito está nas mãos do sistema financeiro [...]. Mas há outros [...] como o financiamento de campanhas políticas, as relações com os membros do Congresso, os 'anéis burocrático-empresariais' [...] e as relações com a mídia [...]. O Banco Central é um membro necessário desta coalizão [...]. Para o estabelecimento da coalizão e da convenção que lhe serve de representação social, basta que o Banco Central e os membros privados derivem benefícios conjuntos da mesma política - no caso, o prestígio de cumprir as metas e os lucros derivados dos altos juros e do câmbio valorizado (Erber, 2011, p. 43).

Finalmente, os parâmetros da função de reação estimada por Modenesi (2011) e por Modenesi et al. (2011) ratificam a visão de que o BCB tem sido altamente

\footnotetext{
${ }^{21}$ No sentido dado por Weber (1991); ver nota 32.

${ }^{22}$ Oreiro (2012) e Correa (2010) aproximam essa tese da formulação de Keynes.

${ }^{23}$ Os economistas ortodoxos têm grande dificuldade em assimilar o correto significado dessa tese provavelmente por transcender a teoria econômica, dado seu viés de economia política. É comum vê-la apresentada de forma totalmente distorcida. Vide Schwartsman (2011), que a interpreta como se ela simplesmente sugerisse haver uma "conspiração" dos analistas do Boletim Focus visando "induzir o BC a definir uma trajetória da taxa de juros mais alta do que a estritamente necessária”. É verdade que o Focus é um dos elementos usados para manter o status quo pelos beneficiários da convenção - inclusive o BCB, como mostrado por Guimarães $(2008,2009)$. Porém, a tese não se reduz a uma mera "conspiração".

${ }^{24}$ Bruno (2007) mostra a financeirização da economia brasileira. Matias (2007, p. 56) assinala a disseminação de "negócios orientados a ganhos financeiros". Lessa (2012) fala do "sonho empresarial de crescer a receita não operacional mediante aplicações e jogos financeiros”.
} 
conservador: os resultados evidenciam uma excessiva lentidão nos movimentos dos juros e um elevado patamar da taxa de juros de equilíbrio. Chernavsky (2007, 2008) também apresenta evidência empírica favorável à tese da convenção.

\section{4 - Concepção Fiscalista}

É muito difundida a proposição de que a Selic, como indexador da dívida pública, deveria ser mantida elevada para induzir os investidores a carregar títulos. Como o estoque da dívida pública é considerado elevado e seu perfil de má qualidade - curta maturidade média e elevada participação de LFT -, o BCB não poderia reduzir a taxa de juros sob pena de comprometer a demanda por títulos e, portanto, o financiamento do déficit orçamentário. ${ }^{25}$ Segundo Barbosa (2006), o efeito contágio entre a dívida e a PM explicaria a manutenção da Selic em patamares elevados: "Essa inter-relação ajuda a entender as razões pelas quais a taxa básica de juros [...] é tão elevada em termos reais" (p. 231; traduzido). Repare que, segundo essa concepção, a Selic tem de permanecer elevada, independentemente do comportamento dos preços. ${ }^{26}$

Delfim Netto (2005), Giambiagi (2002), Pinheiro e Giambiagi (2006), Martone (2007), Oreiro e Paula (2010), entre outros, consideram que a fragilidade das contas públicas explicaria o excesso de rigidez da $\mathrm{PM}^{27}$ De modo geral, os adeptos dessa tese sustentam que zerar (ou pelo menos diminuir) o déficit nominal do setor público seria uma précondição fundamental para a redução da taxa básica de juros: ${ }^{28}$

[o] objetivo de déficit nominal zero [...] criará instantaneamente uma expectativa de baixa do juro real, que facilitará à Secretaria do Tesouro a substituição de parte da dívida selicada para papéis pré-fixados [...]. Com isso caminharemos com relativa rapidez para taxas de juros reais civilizadas. (Delfim Netto, 2005, p. 9)

A concepção fiscalista tem outra versão igualmente popularizada e veiculada ad nauseam pela mídia. Ela sustenta que a Selic é alta por um problema de falta de

\footnotetext{
${ }^{25}$ A dívida brasileira não pode ser considerada elevada segundo os padrões internacionais; seu perfil, sim, é de péssima qualidade.

${ }^{26}$ A rigor, mesmo se a inflação fosse igual a zero, a Selic não poderia ser suficientemente reduzida sob pena de inviabilizar o financiamento do TN.

${ }^{27}$ Segundo Oreiro e Paula (2010): “[...] o Estado brasileiro ainda possui uma postura financeira Ponzi, o que eleva o risco de financiamento do Tesouro aumentando enormemente o poder de mercado dos compradores de títulos, os quais podem exigir taxas de juros mais altas". Cabe notar que os autores consideram outros fatores na explicação das altas taxas de juros, como a existência das LFT.

${ }^{28}$ Pires (2007) avalia empiricamente a chamada proposta de déficit nominal zero e considera que ela "não é condição suficiente embora necessária no longo prazo para a redução das taxas de juros no Brasil” (p. 662). Batista JR. (2005) e Munhoz (2005) opõem-se frontalmente a esta tese.
} 
coordenação entre as políticas fiscal e monetária (Pastore, 2006; Franco, 2006). A política fiscal é considerada demasiadamente expansionista, o que inflaria a demanda agregada e, assim, pressionaria a inflação. ${ }^{29}$ Dado o compromisso com a estabilidade de preços, caberia à PM o papel de anular o efeito expansionista da política fiscal. Neste sentido, trata-se de uma aplicação do conceito de efeito deslocamento: uma expansão dos gastos públicos resultaria em elevação dos juros para desestimular o investimento privado. ${ }^{30}$ Pode-se dizer que essa concepção deriva, em última instância, da visão ortodoxa segundo a qual a inflação é, essencialmente, um problema fiscal: " "[a] história das inflações elevadas é a história dos desequilíbrios fiscais" (Pastore e Pinotti, 2006).

A crença de que o excesso de endividamento e/ou de gastos públicos é responsável pelas altas taxas de juros não deve ser confundida com a tese da baixa eficácia da PM. De acordo com esta, a rigidez monetária decorreria de falhas circunscritas aos canais de transmissão da PM, independentemente da instância fiscal. Já na concepção fiscalista, mesmo resolvidos todos os problemas que comprometeriam a transmissão da PM, a Selic ainda deveria permanecer elevada - seja porque a dívida pública é alta, seja porque o mix monetário-fiscal não é adequado. Ou seja, a flexibilidade ou até mesmo a leniência fiscal é considerada a causa da rigidez monetária.

\section{5 - Incerteza Jurisdicional}

De acordo com Arida et al. (2005) e Bacha (2005), os agentes evitariam aplicar suas poupanças a longo prazo devido à incerteza jurisdicional — risco de descumprimento de contratos sob jurisdição brasileira (manipulação de indexadores, anulação judicial de cláusulas de correção cambial, congelamento de ativos financeiros etc). Essa incerteza inviabilizaria a precificação dos ativos financeiros de longo prazo e, consequentemente, a formação de um mercado de crédito de longo termo. Esse diagnóstico resulta de uma argumentação em que se combinam fatores microeconômicos e institucionais. Ao final, usando um modelo macroeconômico, Arida et al. (2005) concluem que a eliminação da incerteza jurisdicional reduziria a taxa básica de juros necessária para cumprir a meta de inflação.

Embora não de forma explícita, a incerteza jurisdicional está presente na proposta de Arida (2003a, 2003b) de tornar o real plenamente conversível. O risco de

\footnotetext{
${ }^{29}$ Observe-se que os gastos públicos/PIB ficaram relativamente estáveis no período (Vianna et al., 2010).

${ }^{30}$ Durante a revisão final desse artigo identificou-se variante dessa tese: os juros são altos para compensar a insuficiência da poupança doméstica (Goldfajn, 2011; Goldfajn e Bicalho, 2011; SeguraUbiergo, 2012). Além de basear-se no efeito deslocamento, preconiza-se expansão do superávit primário para ampliar a poupança: "mantida a incompatibilidade entre o déficit público e a poupança voluntária [...] é preciso recorrer a taxas de juros extraordinariamente altas para inibir o consumo privado e estimular a poupança. [...] só há uma remédio: [...] reduzir o déficit público” (Resende, 2011). Pessoa (2011) privilegia o aumento da poupança externa.
}

${ }^{31}$ Sargent e Wallace (1981). 
limitação à conversibilidade acarretaria elevação do risco-país e/ou uma depreciação excessiva do real, determinando níveis de taxas reais de juros internas mais elevados do que prevaleceriam se houvesse plena conversibilidade. Bacha (2003) também argumentou em favor da conversibilidade, enquanto Belluzzo e Carneiro (2004) a ela se opuseram. A defesa da proposta foi renovada em Arida (2004), sendo refutada por Oreiro et al. (2004) e Ferrari Filho et al. (2005). Bacha et al. (2007) apresentam evidência de que há uma relação negativa entre o grau de dolarização de uma economia e sua taxa de juros real. Entretanto, os autores ressaltam que o efeito da dolarização sobre os juros é de baixa magnitude.

Como alertam Bresser-Pereira e Silva (2009), essa tese não parece ter sustentação empírica:

[n]o passado, as instituições eram menos desenvolvidas no Brasil e, mesmo assim, a taxa de juros era muito menor. Além disso, as instituições do país, quando não melhores, são bastante semelhantes àquelas encontradas em países com classificação de risco equivalente ou (pior), mas com taxas de juros muito mais baixas. (p. 39)

De fato, no único estudo empírico sobre o tema, Gonçalves et al. (2007) não encontram evidência favorável à tese.

\section{CONSIDERAÇÕES FINAIS E AGENDA DE PESQUISA}

O excesso de rigidez que vem singularizando a PM é fenômeno complexo que não pode ser explicado, isoladamente, por nenhuma das teses apresentadas. Em conjunto, elas deixam claro que se trata de fenômeno em que se entrecruzam fatores de natureza diversa - econômicos stricto sensu, institucionais e até do âmbito da economia política. A principal conclusão é que não se pode esperar que o problema tenha explicação única e simples, dada a multiplicidade de fatores envolvidos. ${ }^{32}$ No Quadro 1, sintetizam-se (com inevitável simplificação) as principais características das cinco teses.

\footnotetext{
32 Assumimos postura metodológica weberiana: o conhecimento é formado pela construção teóricoracional de tipos ideais, obtidos por um recorte da realidade. Como ela é infinita, passível de múltiplas ordenações, torna-se impossível explicar um objeto por todos os vieses possíveis: "todo conhecimento reflexivo da realidade infinita realizado por um espírito humano, finito, se baseia na premissa tácita de que apenas um fragmento da realidade poderá constituir de cada vez o objeto da compreensão científica" (Weber, 1991, p. 29).
} 
Quadro 1: Síntese das Teses

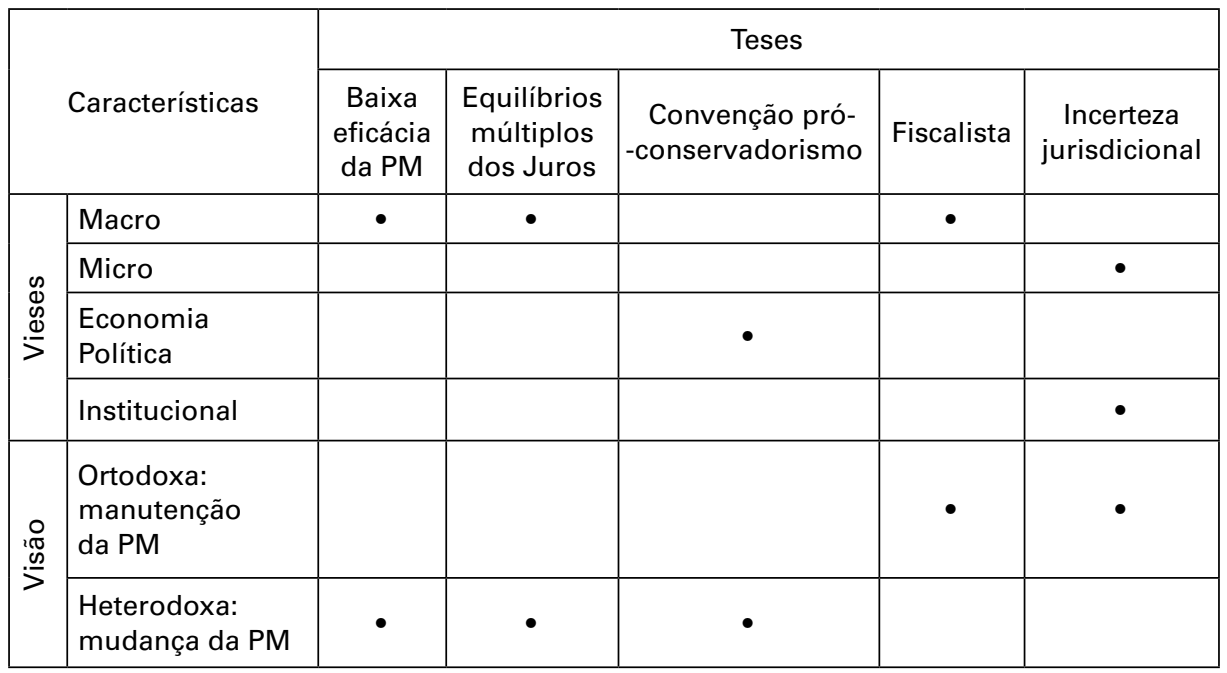

Sem embargo, parece-nos particularmente relevante a hipótese de ineficácia da PM. Isso fica evidente ao se constatar que, apesar de vir praticando por uma década e meia a maior (ou a segunda mais alta) taxa de juros do mundo, o país tem convivido com inflação sistematicamente superior tanto à dos seus pares emergentes quanto à dos nossos vizinhos da AL. Surpreende a persistente coexistência de taxas reais de juros anomalamente altas com elevados níveis de inflação. A inflação vem-se mostrando pouco sensível à Selic. Há forte evidência de que os preços são pouco influenciados pelo nível de atividade econômica. Isso explica por que, a despeito do altíssimo patamar dos juros, o BCB não consegue manter o IPCA em nível muito inferior a 4-5\% a.a. - mesmo durante a recente crise econômica, a maior desde os anos 1930 - o que nos coloca entre os países de mais alta inflação dentre os que adotam o RMI.

Diante disso, economistas mais ortodoxos tendem a considerar que o país simplesmente tem uma taxa de juros natural muito alta e que, portanto, ao BCB resta apenas perseguir esse patamar. Não é essa a nossa visão. Dado o alto custo da PM, cremos que algo deva ser feito. Urge desobstruir os canais de transmissão, tornando a PM mais eficaz. Para tanto, é impostergável a conclusão do processo de desindexação da economia brasileira iniciado com o PR. ${ }^{33}$ O Plano promoveu uma desindexação parcial da economia. Por um lado, parcela relevante de bens e serviços - muitos deles insumos de utilização universal, como aluguel, energia e telefonia - continua tendo seus preços formalmente indexados. ${ }^{34}$ Além disso, na-

\footnotetext{
${ }^{33}$ Bresser e Nakano (2002), Modenesi e Modenesi (2005), Carvalho (2011) e Ferrari Filho et al. (2011).

${ }^{34}$ A MP do real só proibiu a indexação com periodicidade inferior a um ano — apenas alongando-se a memória inflacionária. Ainda é difundida a indexação salarial anual — destacando-se a do salário mínimo.
} 
da foi feito em relação aos ativos financeiros, que também permanecem indexados. Trata-se de herança do período de alta inflação, que se mantém intocada quinze anos após a estabilização dos preços. Sem embargo, finalmente parece estar-se verificando uma espécie de consenso quanto à necessidade de uma nova rodada de desindexação. ${ }^{35} \mathrm{O}$ passo mais imediato nesse sentido é uma repactuação das regras de formação dos preços administrados (pelos três níveis de governo). O fim da indexação dos ativos financeiros - a começar pelas LFT — também é imprescindível. De fato, o problema das LFT é elemento que une autores de diversas orientações teóricas em torno da tese da baixa eficácia da PM. No entanto, a forma como o problema deve ser enfrentado divide ortodoxos e heterodoxos. Os primeiros, apoiando-se na hipótese de mercados eficientes, tendem a considerar como Moraes (2006, p. 259) que as LFT devem "morrer de morte morrida, e não de morte matada". De um ponto de vista mais heterodoxo, propomos que a eliminação das LFT deva ser objetivo prioritário e explícito da política econômica — a ser alcançado de forma ativa, e não passiva.

Mas a precedência conferida à tese da reduzida eficácia da PM deve ser secundada pelo reconhecimento da importância do papel que vem desempenhando a convenção pró-conservadorismo. Como bem diagnosticado por Bresser-Pereira e Nakano (2002), a autoridade monetária incorporou a convenção de que o juro natural da economia brasileira é bastante elevado. Erber (2011) mostra com clareza a relevância dessa convenção. Há uma confluência de interesses em favor da manutenção da Selic elevada e do real sobrevalorizado, envolvendo o BCB, o sistema financeiro e outros agentes privados que se beneficiam da PM vigente. Assim, a convenção pró-conservadorismo é um dos fatores que explicam a resistência em se usar instrumentos alternativos de combate à inflação - a despeito da ampla adesão à tese da ineficácia da PM. Já Bresser-Pereira e Nakano (2002), apontam outro elemento relevante para explicar o problema dos juros. Este resulta da atribuição à taxa Selic de uma multiplicidade de funções, que gera um equilíbrio instável estabelecendo tendência de elevação dos juros. É preciso reformar as instituições monetárias, para preservar a Selic como instrumento estrito de PM.

As hipóteses de baixa eficácia, da convenção e de equilíbrios múltiplos fornecem complexo e poderoso painel explicativo para o problema. ${ }^{36}$ Elas também convergem numa mesma direção: delas pode-se derivar diagnóstico crítico apontando para a necessidade de reformulação da estratégia de estabilização de preços — assumindo, assim, caráter heterodoxo. Por sua vez, economistas de visão mais ortodoxa, de forma geral, sustentam a superioridade do RMI (como o estado das artes em termos de PM) e enfatizam a necessidade da austeridade fiscal — entendendo que robustos superávits primários são condição suficiente para a redução da Selic.

\footnotetext{
${ }^{35}$ Safatle (2011a, 2011b), Delfim Netto (2011a), Valor Econômico (2011) e Megale (2011).

${ }^{36}$ Além da clivagem fundada nos vieses explicativos, as três principais teses podem ser classificadas segundo suas respectivas abordagens analíticas: empírico-institucional; de economia política; e de teoria macroeconômica. Assim, é reforçada a complementaridade e a relevância dessas teses.
} 
Ao se aceitar incondicionalmente a visão fiscalista, oculta-se a dimensão multifacetada do problema, preceituando-se o arrocho fiscal independentemente da origem da pressão inflacionária. Essa é uma abordagem reducionista que tenta dar uma explicação simples para um fenômeno de inegável complexidade. Sua "simplicidade" torna-a de fácil assimilação por parte dos profissionais da mídia e do público. Sua exaustiva repetição a transformou em verdadeiro lugar-comum. A exemplo do que já ocorrera com a visão monetarista da inflação, a tese fiscalista é hoje um dogma do saber convencional. É claro que uma mudança no mix de política econômica que torne a política fiscal mais restritiva pode abrir espaço para uma queda da Selic. No entanto, não se trata de um mero problema de mix, até mesmo porque não se pode dizer que as contas públicas são tão desequilibradas ou que o Estado é Ponzi. Ademais, a geração de superávits primários, por uma década, não teve o efeito antiinflacionário esperado pelos adeptos dessa tese ainda carecendo de evidência empírica robusta.

Em suma, das três análises de natureza genuinamente macroeconômica, a visão fiscalista não propõe mudança na PM. Ao passo que a quase generalidade das contribuições à tese da baixa eficácia da PM, bem como a tese de equilíbrios múltiplos da taxa de juros convergem noutro sentido: um diagnóstico crítico apontando a necessidade de uma nova política antiinflacionária. Neste mesmo sentido aponta - pelo viés da economia política - a tese da convenção pró-conservadorismo na PM.

Finalmente, a hipótese da incerteza jurisdicional mescla preponderantemente o viés institucional e o microeconômico, dela não resultando apreciação específica sobre a PM. É a tese de menor poder explicativo, tendo sua irrelevância empírica sido reconhecida por Resende (2011).

Como pano de fundo, cabe lembrar que a teoria macroeconômica é historicamente marcada por uma polarização incontornável. De um lado, tem-se uma visão dominante ou ortodoxa fundada nas hipóteses de mercados eficientes (HME) e de existência da taxa natural de desemprego. A moeda é considerada neutra e o RMI é tido como a melhor estratégia de condução da política monetária: a taxa de juros é o instrumento mais indicado para debelar as pressões inflacionárias - independentemente de sua natureza. Por outro lado, há um pensamento de caráter heterodoxo, apoiado na hipótese de mercados imperfeitos (HMI) e no princípio da demanda efetiva (PDE). A neutralidade da moeda é negada e questiona-se a superioridade do RMI: pressões inflacionárias com causas distintas devem ser combatidas com diferentes instrumentos - monetários e não monetários. Não deve ser delegada apenas ao BCB a tarefa de se manter os preços estáveis. ${ }^{37}$

A discussão teórica sobre a condução da PM enquadra-se nessa oposição dual e irredutível resultante da aceitação, por cada polo doutrinário, de um conjunto de postulados e, a fortiori, da negação do outro: HME, taxa natural de desemprego e

${ }^{37}$ Para apresentação mais sistematizada, ver Modenesi (2005a, cap. 3). 
neutralidade da moeda versus HMI, PDE e não neutralidade. Assim, parece difícil o avanço desse debate: as arestas a serem aparadas são de ordem axiomática. ${ }^{38}$

Já na área da economia política, o campo é muito fértil. Inicialmente, cabe aprofundar a discussão teórica - esta não é uma tarefa apenas dos economistas. Primeiro, a propósito da não neutralidade das decisões de $\mathrm{PM}-\mathrm{o}$ fato de que a PM afeta os grupos de interesse de forma diferenciada, gerando ganhadores e perdedores. Segundo, a respeito do papel desempenhado pela convenção pró-conservadorismo na manutenção do RMI, apesar da ampla aceitação da tese da ineficácia. No terreno empírico, encontra-se o desafio de se mensurar os ganhos e as perdas dos diferentes grupos de interesse.

Quanto à tese da ineficácia da PM, identificam-se boas oportunidades de investigação. As de natureza empírica são:

1) o aprofundamento da comprovação da perda de eficácia da $\mathrm{PM}$ - mais evidência deve ser buscada, notadamente em face das limitações empírico-metodológicas subjacentes aos trabalhos apontando o problema;

2) o aprimoramento da mensuração do grau de ineficácia da PM - os diferentes canais de transmissão devem ser tratados isoladamente e de forma mais minuciosa;

3) o efeito renda financeira às avessas também merece especial atenção — visando obter evidência mais conclusiva quanto a sua relevância;

4) o canal de custos ainda carece de comprovação empírica mais robusta; e

5) do ponto de vista microeconômico, falta investigar a importância dos oligopólios e/ou das altas margens de lucro praticadas no país enquanto fator explicativo para a persistência da inflação em níveis elevados. ${ }^{39}$

A partir de um marco teórico heterodoxo, cabe avançar em pelo menos duas frentes:

6) a ineficácia da PM (somada às críticas teóricas ao RMI) requer o aprimoramento dos instrumentos alternativos de combate à inflação — a serem utilizados em conjunto ou em substituição à Selic; ${ }^{40} \mathrm{e}$

7) considerando-se que a moeda não é neutra no longo prazo, a discriminação de preços em favor do investimento subjacente ao uso da TJLP pode potencializar a PM. Isso ainda está para ser modelado e testado empiricamente.

Com este artigo não se pretende limitar o debate, mas sim, destacar um conjunto de temas de promissora investigação.

\footnotetext{
${ }^{38}$ Essa clivagem é usada por Carvalho (2006).

${ }^{39}$ Setores mais concentrados (ou oligoplizados) tendem a ser mais inflacionários por pelo menos duas razões: têm maior capacidade de repassar para os preços aumentos de custo; e são relativamente imunes aos efeitos contracionistas da PM, visto que não necessariamente concorrem via preço. Neste aspecto, o resgate da abordagem estruturalista da inflação é promissor (Sunkel, 1958; Oliveira, 1960; Rangel; 1963).

${ }^{40}$ Carvalho (1994, 1995a, 1995b), Sicsú (2003), Braga (2011) e Ferrari Filho e Modenesi (2011a, 2011b).
} 


\section{REFERÊNCIAS BIBLIOGRÁFICAS}

AMARAL, R. Q. (2009). “Armadilha do regime monetário brasileiro: a existência de equilíbrios múltiplos”. In: J. L. Oreiro, L. F. de Paula e R. Sobreira (Orgs.). Politica monetária, bancos centrais e metas de inflação. Rio de Janeiro: Editora FGV.

ANDIMA (2003). Divida Pública: proposta para ampliar a liquidez. Rio de Janeiro: Andima.

ANDRADE, J. P. e PIRES, M. C. C. (2009). “A transmissão da política monetária pelo canal do efeito riqueza no Brasil”. In J. L. Oreiro, L. F. de Paula e R. Sobreira (Orgs.). Política monetária, bancos centrais e metas de inflação. Rio de Janeiro: Editora FGV.

ARAÚJO, E. e MODENESI, A. M. (2010a). "Custos e Benefícios do Controle Inflacionário no Brasil (2000-2008): uma análise empírica do mecanismo de transmissão da política monetária com base em um modelo VAR". XXVIII Encontro Nacional de Economia.

. (2010b). "A Importância do Setor Externo na Evolução do IPCA (1999-2010): uma análise com base em um modelo SVAR". XXVIII Encontro Nacional de Economia.

ARESTIS, P., PAULA, L. F. de e FERRARI-FILHO, F. (2009). "A nova política monetária: uma análise do regime de metas de inflação no Brasil”. Economia e Sociedade, v. 18 (1), pp. 1-30.

ARIDA, P. (2003a). “Múltiplos equilíbrios”. Revista de Economia Política, v. 22 (3), pp. 122-31. . (2003b). "Por uma moeda plenamente conversível”. Revista de Economia Política, v. 23 (3), pp. $135-42$.

"Ainda sobre a conversibilidade". Revista de Economia Política, v. 23 (3), pp. 151-4.

. (2004). "Aspectos macroeconômicos da conversibilidade: uma discussão do caso brasileiro". Mimeo.

(2005). "Mecanismos compulsórios e mercado de capitais: propostas de política econômica". In E. L. BACHA e L. C. OLIVEIRA FILHO (Orgs.). Mercado de capitais e crescimento econômico lições internacionais, desafios brasileiros. Rio de Janeiro: Contra Capa.

ARIDA, P. BACHA, E. e RESENDE, A. L. (2005). “Credit, Interest and Jurisdictional Uncertainty: Conjectures on the Case of Brazil”. In F. GIAVAZZI, I. GOLDFAJN e S. HERRERA (Orgs.). Inflation Targeting, Debt, and the Brazilian Experience: 1999 to 2003. Cambridge: MIT Press.

BACHA, E. L. (2003). "Reflexões pós-cepalinas sobre inflação e crise externa”. Revista de Economia Política, v. 23 (3), pp. 143-50.

. (2005). "Incerteza jurisdicional e crédito de longo prazo". In: E. L. BACHA e L. C. OLIVEIRA FILHO (Orgs.). Mercado de capitais e crescimento econômico lições internacionais, desafios brasileiros. Rio de Janeiro: Contra Capa.

BACHA, E. L., HOLLAND, M. e GONÇALVES, F. M. (2007). “Is Brazil different? Risk, dollarization, and interest rates in emerging markets", IMF Working Paper 07/294.

BACHA, E. L. e OLIVEIRA FILHO, L. C. (2006) (Orgs.). Mercado de Capitais e Dívida Pública: tributação, indexação e alongamento. Rio de Janeiro: Contra Capa.

BARBOSA, F. H. (1982). "Inflação, Taxa de Juros e o Fenômeno da Ultrapassagem”. Estudos Econômicos, v. 12 (1), pp. 51-61.

(1991). “O Mercado Aberto Brasileiro: Análise dos Procedimentos Operacionais”. Revista Brasileira de Mercado de Capitais, v. 16 (43), pp. 36-60.

. (1993). “A Indexação dos Ativos Financeiros: A Experiência Brasileira”. Revista Brasileira de Economia, v. 47 (3), pp. 373-97.

. (2003). “A Estabilização Inacabada”. Revista de Economia Mackenzie, v. 1 (1), pp. 13-26.

. (2004). "A Inércia da Taxa de Juros na Política Monetária”. Revista de Economia Política, v. 30

(2), pp. 105-19.

. (2005). “O mistério da taxa de juros real”. Conjuntura Econômica, p.13, nov.

. (2006). "The contangion effect of public debt on monetary policy: the Brazilian experience". Revista de Economia Política, v. 26 (2), pp. 231-8.

BARBOSA, F. H., PEREIRA, P. L. V. e SALLUM, E. M. (1995). “A Substituição de Moeda no Brasil: A Moeda Indexada”. Pesquisa e Planejamento Econômico, v. 25 (3), pp. 407-26.

BATISTA JR., P. N. (2005). “Juro: algoz da dívida pública”. Jornal dos Economistas, 197, pp. 3-4. 
BELLUZZO, L. G. e CARNEIRO, R. (2004). "O mito da conversibilidade”. Revista de Economia Política, v. 24 (2), pp. 218-22.

BEVILAQUA, A. MESQUITA, M. e MINELlA, A. (2007). "Brazil: Taming inflation expectations”, $B C B$ Working Paper, 129.

BLANCHARD, O. (2004). "Fiscal Dominance and Inflation Targeting. Lessons from Brazil". NBER Working Paper, 10389.

BRAGA, J. M. (2011). “A infação brasileira na decada de 2000 e a importância de políticas não monetárias de controle”. IPEA: Seminários Dimac, 374.

BRESSER-PEREIRA, L. C. (1992). “O Décimo Primeiro Plano de Estabilização”. In: J. P. Velloso (Org.), Combate à Inflação e Reforma Fiscal. Rio de Janeiro: José Olympio.

BRESSER-PEREIRA, L. C. e NAKANO, Y. (2002). "Uma Estratégia de Desenvolvimento com Estabilidade”. Revista de Economia Política, v. 22 (3), pp. 146-80.

BRESSER-PEREIRA, L. C. e SILVA, C. G. da (2009). "O regime de metas de inflação no Brasil e a armadilha da taxa de juros/taxa de câmbio”. In J. L. Oreiro, L. F. de Paula e R. Sobreira (Orgs.). Política monetária, bancos centrais e metas de inflação. Rio de Janeiro: Editora FGV.

BRUNO, M. A. P. (2007). "Financiarisation et accumulation du capital productif au Brésil. les obstacles macro-économiques à une croissance soutenue”. Revue Tiers Monde, v. XLVIII, pp. 65-92.

. (2010). "Endividamento do Estado e Setor Financeiro no Brasil: interdependências macroeconômicas e limites estruturais ao desenvolvimento". In CORECON (Org.). Os Anos Lula: contribuições para um balanço crítico 2003. Rio de Janeiro: Garamond.

CÂMARA NETO, A. F. e M. VERNENGO (2002). "Uma releitura heterodoxa de Bresser-Nakano". Revista de Economia Política, v. 22 (4), pp. 152-55.

CARVALHO, F. J. C. (1994). “Temas de política monetária keynesiana”. Ensaios FEE, v. 15 (1), pp. 33-61.

. (1995a). "Estabilização ancoragem de preços e política de rendas". Novos Estudos CEBRAP, 41, pp. 143-9.

. (1995b). "Política de rendas: ganhos e perdas da intervenção no sistema de preços". Estudos Econômicos, v. 25 (3), pp. 297-328.

(2004). "Teoria e política monetárias: uma visão pessoal sobre uma relação difícil”. Econômica, v. 6 (2). pp. 315-34.

. (2005). "Uma contribuição ao debate em torno da eficácia da política monetária e algumas implicações para o caso do Brasil”. Revista de Economia Política, v. 25 (4), pp. 323-36.

. (2006). "Controles de Capitais: uma agenda de pesquisa”. In J. SICSÚ e F. FERARI FILHO

(Orgs.). Câmbio e Controle de Capitais: avaliando a eficiência de modelos macroeconômicos. Rio de Janeiro: Elsevier.

. (2011). "A inflação e o crescimento". Valor Econômico, p. A-16, 20/06.

CHERNAVSKY, E. (2007). "Sobre a construção da política econômica: uma discussão dos determinantes da taxa real de juros no Brasil”. USP, Dissertação de mestrado.

. (2008). "Taxa natural e convenções: uma discussão dos determinantes da taxa real de juros no Brasil”. XIII Encontro de Economia Política.

CORREA, L. S. C. (2010). “Convenções financeiras e a taxa de juros no Brasil”. Unicamp, Dissertação de mestrado.

DAVIDSON, P. (1978). Money and the Real World. London: Macmillan. (2003). Post Keynesian Macroeconomic Theory. Cheltenham: Edward Elgar.

DELFIM NETTO, A. (2005). "Déficit Nominal Zero". Economia \& Tecnologia, 01, v. 02. . (2011a). "Um voto de confiança”. Valor Econômico, pp. F 4-5, 30/04.

(2011b). "Boa oportunidade”. Valor Econômico, p. A-2, 14/06.

ERBER, F. (2008a). "Development projects and growth under finance domination - the case of Brazil during the Lula years (2003-2007)". Revue Tiers Monde, 194.

. (2008b). "The Evolution of Development Conventions". XII ISS Conference.

(2011). "As convenções de desenvolvimento no Brasil: um ensaio de economia política”. Revis-

ta de Economia Política, vol. 31(1), pp. 31-55. 
FAVERO, C. A. e GIAVAZZI, F. (2002). “Why are Brazil's interest rates so high?”. IGER Working Paper, 224.

FERRARI FILHO, F. MENDONÇA, H. F. e SOBREIRA, R. (2003). "Proposta de Regime Cambial para a Economia Brasileira”. In J. Scisú, J., L. Oreiro e L. F. de Paula (Orgs.). Agenda Brasil: Políticas econômicas para o crescimento com estabilidade de preços. Barueri: Manole, pp. 153-200.

FERRARI FILHO, F., JAYME JR., F. G., LIMA, G. T., OREIRO, J. L., PAULA, L. F. de (2005). ”Uma avaliação crítica da proposta de conversibilidade plena do real". Revista de Economia Política, v. 25 (1), pp. 133-51.

FERRARI FILHO, F., e MODENESI, A. M., (2011a). "Faz sentido controlar a inflação elevando a Selic?” Valor Econômico, p. A-14, 21/06.

- (2011b). "Choques de oferta, indexação e política monetária: breves considerações sobre a aceleração inflacionária recente”. Economia \& Tecnologia,V. 26, pp. 5-13.

FERRARI FILHO, F., MODENESI, A. M., e MODENESI, R. L. (2011). "Desindexar ainda é preciso". Valor Econômico, p. A-10, 05/07.

FIGUEIREDO, F. M. R. e FERREIRA, T. P. (2002). "Os preços administrados e a inflação no Brasil". Trabalhos para Discussão, 59, Banco Central do Brasil.

FONSECA, M. W. (2009) "Política monetária e o canal do crédito no Brasil: uma revisão da literatura". In: J. L. Oreiro, L. F. de Paula e R. Sobreira (orgs.). Política monetária, bancos centrais e metas de inflação. Rio de Janeiro: Editora FGV.

FRANCO, G. H. B. (2005). "A inflação (a nova) e a política monetária (a velha)”. Veja, p. 105, 02/03. (2006). “A culpa não é do banco central”. Valor Econômico, Eu \& Fim de Semana, p. 16, $27 / 01$.

FRÓES, F. MODENESI, R. L. e MODENESI, A. M. (2005). “O esgotamento da política monetária”. O Estado de São Paulo, B-2, 15/07.

GIAMBIAGI, F. (2002). “Um cenário normativo para a economia brasileira com reforma tributária e controle do gasto público". Texto para Discussão, 92, BNDES. . (2007). Brasil, raízes do atraso: paternalismo $x$ produtividade. Rio de Janeiro: Elsevier.

GOLDFAJN, I. (2011). “A longa travessia para normalidade: juros reais no Brasil”. Valor Econômico, p. A-14, 27/06.

GOLDFAJN, I. e BICALHO, A. (2011). “A longa travessia para a normalidade: os juros reais no Brasil”. In BACHA, E. e DE BOLLE, M. (Orgs.), Novos Dilemas da Política Econômica. Ensaios em homenagem a Dionísio Dias Carneiro. Rio de Janeiro: LTC.

GOMES, C. e HOLLAND, M. (2003). "Regra de Taylor e Política Monetária em Condições de Endividamento Público". Revista Economia, v. 4 (2), p. 333-60.

GONÇALVES, F. M., HOLLAND, M. e SPACOV, A. D. (2007). "Can jurisdictional uncertainty and capital controls explain the high level of real interest rates in Brazil? Evidence from panel data". Revista Brasileira de Economia, 61, pp. 49-75.

GUIMARÃES, L. S. (2008). “Jogo de espelhos intensifica aperto”. Valor Econômico, p. C-2, 08/04.

GUIMARÃES, L. S. (2009). “Crescem pressões pela alta dos juros”. Valor Econômico, p. C-2, 09/10.

HOLLAND, M. (2006). “Por que as taxas de juros de curto prazo são tão elevadas no Brasil?”. Economia \& Tecnologia, v. 4, pp. 27-42.

KEYNES, J. M. (1936), The General Theory of Employment, Interest and Money. London: Macmillan. (1937). "The general theory of employment". The quarterly Journal of Economics, v. 51 (2), pp. 209-23.

LESSA, C. (2012). “Uma pauta para opções não ingênuas”. Valor Econômico, p. A-15, 07/03.

LOPES, F. (1997). "O mecanismo de transmissão da política monetária numa economia em processo de estabilização: notas sobre o caso do Brasil”. Revista de Economia Política, v. 17 (3). pp. 5-11.

KREGEL, J. (2004). "Comment on Fernando Cardim de Carvalho - Monetary policy, monetary theory, and financial structure”. Econômica, v. 6, n. 2, pp. 341-8.

MARQUES, A. M. e FOCHEZATTO, A. (2006). "Importância do canal do custo na transmissão dos efeitos da taxa de juros sobre os preços na economia brasileira, 1994-2005”. XI Encontro Nacional de Economia Política. 
MARTONE, C. (2007). “Juros e ajuste fiscal: comentários”. IN C. A. Rocca (Org.), Mercado de Capitais, Agenda de Reformas e Ajuste Fiscal. Rio de Janeiro: Campus.

MATIAS, A. B. (2007). "Condições estruturais do sistema bancário brasileiro: spread, taxa de juros, concorrência”. IN C. A. Rocca (Org.), Mercado de Capitais, Agenda de Reformas e Ajuste Fiscal. Rio de Janeiro: Campus.

MEGALE, C. (2011). "O desafio da desindexação além dos preços e salários". Valor Econômico, p. A-8, 23/05.

MEIRELLES, H. (2010). “Crédito do BNDES leva a Selic Mais alta”. Valor Econômico, p. C-8, 05/06.

MENDONÇA, H. F., DEZORDI, L. L. e CURADO, M. L. (2009). "A determinação da taxa de juros em uma economia sob metas de inflação: o caso brasileiro". In J. L. Oreiro, L. F. de Paula e R. Sobreira (Orgs.). Política monetária, bancos centrais e metas de inflação. Rio de Janeiro: Editora FGV.

MINELLA, A., FREITAS, P. S., GOLDFAJN, I. e MUINHOS, M. K. (2003). "Inflation targeting in Brazil: constructing credibility under Exchange rate volatility". Journal of international Money and Finance, v. 27 (7), pp. 1015-40.

MODENESI, A. M. (2003). "Regimes Monetários: Fundamentos Teóricos e a Experiência do Plano Real”. UFF, Dissertação de mestrado. . (2004). “A economia está se reindexando. Isso é grave”. Jornal do Brasil, 30/05, p. A-31. (2005a). Regimes Monetários: Teoria e a Experiência do Real. Barueri: Manole. (2005b). "Preços administrados comprometem crescimento". Valor Econômico, 05/09, p. A-10. (2006a). "Trégua provisória e ilusória”. Jornal do Commercio, 09/01, p. A-2. (2006b). "Porque a taxa de juros é tão alta no Brasil”. Valor Econômico, 12/06, p. A-10. (2011). "Conservadorismo e Rigidez na Política Monetária: uma estimativa da função de reação do BCB (2000-2007)”. Revista de Economia Política, v. 31 (3), pp. 415-34.

MODENESI, A. M. e MODENESI, R. L. (2005). “Desindexar é preciso”. Jornal dos Economistas, pp. 10-1, set.

MODENESI, A. M., MODENESI, R. L. e N. M. MARTINS (2011). "A Modified Taylor Rule for Brazilian Economy: convention and conservatism in 11 years of inflation targeting (2000-2010)". XXXIX Encontro Nacional de Economia.

MORAES P. L. B. (2006). “As Letras Financeiras do Tesouro e o alongamento da dívida pública”. In: BACHA, E. L. e OLIVEIRA FILHO, L. C. (Orgs.), Mercado de Capitais e Dívida Pública: tributação, indexação e alongamento. Rio de Janeiro: Contra Capa.

MUNHOZ, D. G. (2005). “Déficit zero é uma estupidez”. Jornal dos Economistas, 197, pp. 7-9.

NAKANO, Y. (2005). "O regime monetário, a dívida pública e a alta taxa de juros". Conjuntura Econômica, pp. 10-2, nov.

(2006). "Antes que os populistas tomem conta". Valor Econômico, 17/01.

(2011). "Aprimorar para reduzir a meta”. Valor Econômico, 11/01, p. A-11.

NOGUEIRA JR., R. P. (2007). "Inflation targeting and exchange rate pass-through”. Economia Aplicada, São Paulo, v.11 (2), pp. 189-208.

OLIVEIRA, J. (1967). "La Inflación Estructural y el Estructuralismo Latinoamericano”. In: SUNKEL, O. et al. Inflación y Estructura Económica. Buenos Aires: Paidós.

OREIRO, J.L. (2002). "Prêmio de Risco Endógeno, Metas de Inflação e Câmbio Flexível: implicações da hipótese Bresser-Nakano para uma pequena economia aberta”. Revista de Economia Política, v. 22 (3), pp. 107-22.

. (2012). “Keynes e os juros”. Valor Econômico, p. A-14, 05/mar.

OREIRO, J. L., PAULA, L. F. e SILVA, G. J. C. da (2004). "Por uma moeda parcialmente conversível: uma crítica a Arida e Bacha”. Revista de Economia Política, v. 24 (2), pp. 223-37.

OREIRO, J. L. e PAULA, L. F. de. (2010). “Por que a taxa de juros é tão alta?” Valor, p. A-17, 05/11.

OREIRO, J. L., PAULA, L. F. de, SILVA, G. J. C. da, AMARAL, R. Q. do. (2007), "Por que o custo do capital no Brasil é tão alto?”. XXXV Encontro Nacional de Economia.

PARREIRAS, M. A. (2007). "A estrutura institucional da dívida pública brasileira e seus impactos sobre a gestão da política monetária: uma análise empírica do regime de metas para a inflação”. USP, Dissertação de mestrado.

. (2008). “A dívida pública e a gestão da política monetária no regime de metas”. Informativo Fipe, pp. 30-4, abr. 
PASTORE, A. C. (1996). “Por que a política monetária perde eficácia?”. Revista Brasileira de Economia, v. 50 (3).

(2006). "Gastar menos e crescer mais". Valor Econômico, Eu \& Fim de Semana, pp. 10-4, $27 / 01$.

PASTORE, A. C. e PINOTTI, M. C. (2006). “Ajuste fiscal: o que diz o último capítulo?” Valor Econômico, p. A-11, 24/04.

PAULA, L.F. de. (2009). "Autonomia do banco central: estabilidade de preços ou estabilidade macoeconômica?”. In J.L. Oreiro, L.F. de Paula e R. Sobreira (Orgs.). Política monetária, bancos centrais e metas de inflação. Rio de Janeiro: Editora FGV.

. (2011). "O problema da taxa de juros no Brasil". Carta Maior, 10/03.

(2012). "Liberalizar, uma boa ideia?” Valor Econômico, p. A-13, 08/03.

PAULA, L. F. de. e PIRES, M. C. C. "Determinantes macroeconômicos do spread bancário: uma análise preliminar para economias emergentes”. In L. F. de PAULA e J. L. C. OREIRO (Orgs.). Sistema Financeiro: uma análise do setor bancário brasileiro. Rio de Janeiro: Elsevier.

PESSOA, S. (2011). “A estabilização incompleta”. Valor Econômico, p. A-16, 14/06.

PINHEIRO, A. C. e GIAMBIAGI, F. (2006). Rompendo o marasmo: a retomada do desenvolvimento no Brasil. Rio de Janeiro: Elsevier.

PIRES, M. C. C. (2007). "Uma análise da proposta de déficit nominal zero". Revista de Economia Política, vol. 27 (4), pp. 651-63.

. (2008). "Interação entre política monetária e fiscal no Brasil em modelos robustos a pequenas amostras". UNB, Tese de doutorado.

RANGEL, I. (1963). A Inflação Brasileira. Rio de Janeiro: Tempo Brasileiro.

RESENDE, A. L. (2011). “Juros: equívoco ou jabuticaba?”. Valor Econômico, p. A-16, 16/06.

RODRIGUES, R. S. e BASTOS, C. P. (2010). “Análise recente das finanças públicas e da política fiscal no Brasil”. III Encontro Internacional da Associação Keynesiana Brasileira.

ROMER, D. (2001). Advanced Macroeconomics. New York: MacGraw Hill.

SAFATLE, C. (2011a). “Governo prepara proposta de desindexação”, p. A-2, 29/04. (2011b). "O santo ainda é de barro". Valor Econômico, p. F-1, 30/04.

SARGENT, T. e WALLACE, N. (1981). "Some unpleasant monetarist arithmetic". Federal Reserve Bank of Minneapolis Quarterly Review, 5, pp. 1-17.

SAYAD, J. (2005). “Dívida Pública: quarenta anos de frustrações”. In F. Mendonça (Relator), A Dívida Pública Brasileira. Cadernos de Altos Estudos, 2. Câmara dos Deputados. Brasília: Plenarium.

SCHWARTSMAN, A. (2011). “À caça do mensageiro”. Valor Econômico, p. A-12, 05/05.

SEGURA-UBIERGO, A. (2012). "The Puzzle of Brazil's High Interest Rates". IMF Working Paper, $12 / 62$

SERRANO, F. (2006). "Taxa de juros, taxa de câmbio e metas de inflação". Valor Econômico, 24/03, p. A-23.

SICSÚ, J. (2003). "Políticas não monetárias de controle da inflação da inflação: uma proposta pós-keynesiana". Análise Econômica, v. 21 (1), pp. 115-36.

SILVA, G.J., OREIRO, J. L. C. e PAULA, L. F. de. (2007). "Spread bancário no Brasil: uma avaliação empírica recente”. In L. F. de PAULA e J. L. OREIRO (Orgs.). Sistema Financeiro. Uma análise do setor bancário brasileiro. Rio de Janeiro: Elsevier.

SOUZA, E. B. M. (2011). “Por que a inflação não cai mais rápido?”. Valor Econômico, p. A-13.

SUNKEL, O. (1958). "La Inflación Chilena: un Enfoque Heterodoxo". El Trimestre Económico, v. XXV (4).

TENAI, P. (2006). “Ciclo sem precedente de alta dos juros”. Valor Econômico, p. A-12, 12/05.

VALOR ECONÔMICO (2011). "Inflação e indexação, causas ou efeitos?”. Valor Econômico, p. A-12, $30 / 04$.

VIANNA, S. W., BRUNO, M. A. P. e MODENESI, A. M. (Orgs.) (2010). Macroeconomia para o Desenvolvimento: crescimento emprego e estabilidade. Rio de Janeiro: IPEA.

WEBER, M. (1991). "A Objetividade do conhecimento nas ciências sociais e políticas". In Sobre a Teoria das Ciências Sociais. São Paulo: Moraes.

WERLANG, S. (2003). "Uma releitura de Bresser-Nakano”, Folha de São Paulo, 01/03. 